Fadhil, et al/Jurnal Ekonomi Syariah Teori dan Terapan Vol. 6 No. 8 Agustus 2019: 1674-1689; PENGARUH

FAKTOR SOSIAL EKONOMI TERHADAP PERKAWINAN MUSLIM DI INDONESIA

\title{
PENGARUH FAKTOR SOSIAL EKONOMI TERHADAP PERKAWINAN MUSLIM DI INDONESIA ${ }^{1}$
}

\section{Fauzia Aqilla Fadhil}

Departemen Ekonomi Syariah - Fakultas Ekonomi dan Bisnis - Universitas Airlangga

Email: fauzia.aqilla.fadhil-2015@feb.unair.ac.id

\section{Ilmiawan Auwalin}

Departemen Ekonomi Syariah - Fakultas Ekonomi dan Bisnis - Universitas Airlangga Email: auwalin@feb.unair.ac.id

\begin{abstract}
:
This study aims to find out what factors that affect a Muslim's decision to get married. This study uses the data from the Indonesian Family Life Survey (IFLS) with a quantitative approach using $83 \%$ of the sample population in Indonesia covering approximately 30,000 people taken in 13 of the 27 provinces in Indonesia. This study was analyzed using Linear Probability Model (LPM) regression, Logit regression and Probit regression. The data in this study were processed using STATA MP software. According to the results of data using three regression models, the factors that affect the decision of each individual in Indonesia in general to marry are gender, religion, age, education and occupation. The factors that affect each individual Muslim in Indonesia to make a decision to marry are gender, age, education and occupation. Then, for women in Indonesia in general, the factors that affect the decision to get married are religion, age, and occupation. Last but not least, for Muslim women, the factors that affect the decision to marry is age and occupation.
\end{abstract}

Keywords: Socio-Economy, Muslim Marriage, Marital Decision

\section{PENDAHULUAN}

Menurut perwakilan BKKBN (Badan

Kependudukan dan Keluarga Berencana Nasional), usia ideal seorang perempuan untuk menikah adalah 21 tahun, sedangkan untuk pria adalah 25 tahun. UU No. 1 tahun 1974 tentang perkawinan yang menyatakan bahwa wanita boleh menikah saat sudah mencapai umur 16 tahun di saat pria adalah 19 tahun.

Biro Sensus AS pada tahun 2013 menyatakan bahwa usia ideal seseorang untuk menikah adalah mulai usia 27 tahun untuk perempuan dan 29 untuk laki-laki (hellosehat.com). Salah satu faktor yang menentukan usia ideal tersebut adalah sudah adanya kedewasaan. Dewasa yang dimaksud bukan hanya bertambahnya umur, namun juga kematangan pola pikir, dan kecerdasan emosional.

Di usia pertengahan 20-an, manusia dianggap sudah cukup cerdas dalam mengelola emosi, dalam menghadapi konflik, terutama saat berumah tangga nanti. Di usia ini manusia terhitung mampu membedakan mana cinta yang hanya berlandaskan nafsu, dan cinta yang tulus. Pada usia ini, seseorang telah sibuk mencari jati dirinya, dan mengalami banyak ujian hidup, sehingga seseorang dalam usia ini

${ }^{1}$ Jurnal ini merupakan bagian dari skripsi Fauzi Aqilla Fadhil, NIM: 04151 1433082, yang diuji pada tanggal 25 Juni 2019. 
Fadhil, et al/Jurnal Ekonomi Syariah Teori dan Terapan Vol. 6 No. 8 Agustus 2019: 1674-1689; PENGARUH FAKTOR SOSIAL EKONOMI TERHADAP PERKAWINAN MUSLIM DI INDONESIA

dianggap sudah mampu menghadapi berbagai tantangan kehidupan selanjutnya dan akhirnya mengetahui pasti apa yang mereka benar-benar inginkan dalam hidup. Mereka juga mengerti apa saja hak dan tanggung jawab yang dimilikinya demi mencapai tujuan hidup.

Menurut Kepala BKKBN RI, Surya Chandra Surapaty, menikah terlalu muda mempunyai risiko tinggi, karena fungsi organ reproduksi yang belum matang. Hal ini juga berlaku bagi wanita yang menikah terlalu tua, seperti di atas 35 tahun.Risiko yang terjadi dapat berupa pendarahan yang banyak saat melahirkan, karena telah melemahnya fungsi organ reproduksi (jpp.go.id).

Dalam Islam, perkawinan adalah fithrah kemanusiaan, maka dari itu Islam menganjurkan untuk nikah, karena nikah merupakan gharizah insaniyah (naluri kemanusiaan). Bila gharizah ini tidak dipenuhi dengan jalan yang sah yaitu perkawinan, maka ia akan mencari jalanjalan syetan yang banyak menjerumuskan ke lembah hitam. Firman Allah Ta'ala:
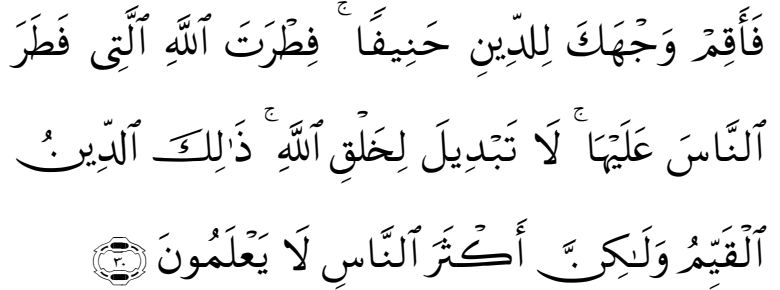

Fa-aqim wajhaka li-ddiini haniifan fithratallahillatii fatharannaasa 'alaihaa laa tabdiila likhalqillahi dzalikaddiinul qai-yimu walakinna aktsarannaasi laa ya'lamuun(a) Artinya: "Maka hadapkanlah wajahmu dengan lurus kepada agama (Allah); (tetaplah atas) fitrah Allah yang telah menciptakan manusia menurut fitrah itu. Tidak ada perubahan pada fitrah Allah. (Itulah) agama yang Iurus; tetapi kebanyakan manusia tidak mengetahui". [Q.S. Ar-RuUm : 30].

Menurut Rahmat Hakim, kata 'nikah' berasal dari bahasa Arab 'nikah' yang merupakan mashdar atau asal kata dari kata kerja (fi'il madhi) 'nakaha' sinonimnya 'tazawwaja' kemudian diterjemahkan dalam bahasa Indonesia sebagai perkawinan (Tihami dan Sahrani 2009:7). Terkadang, perkawinan juga disebut dengan pernikahan. Dalam bahasa Indonesia, kata "kawin" menurut bahasa adalah membentuk keluarga dengan lawan jenis, atau melakukan hubungan badan. Istilah "kawin" biasa digunakan secara umum untuk tumbuhan, hewan dan manusia dan menunjukkan proses generatif secara alami. Di lain pihak kata nikah hanya digunakan pada manusia, karena mengandung kabsahan yang tepat dilihat dari perspektif hukum nasional, ada istiadat, norma, dan agama.

Pernikahan mempunyai pengaruh bagi pertumbuhan jumlah penduduk. Pertumbuhan penduduk sebenarnya mempunyai pergerakan yang dinamis, 
Fadhil, et al/Jurnal Ekonomi Syariah Teori dan Terapan Vol. 6 No. 8 Agustus 2019: 1674-1689; PENGARUH FAKTOR SOSIAL EKONOMI TERHADAP PERKAWINAN MUSLIM DI INDONESIA

dengan pengertian bahwa masyarakat akan bertambah atau berkurang. Perkembangan penduduk akan dipengaruhi oleh jumlah bayi yang lahir tetapi secara bersamaan pula akan dikurangi oleh jumlah kematian yang dapat terjadi pada semua golongan umur. Peningkatan pertumbuhan penduduk yang besar bagi beberapa kalangan merupakan sebuah hal yang positif, karena jumlah penduduk dapat dijadikan subjek pembangunan, dan perekonomian akan berkembang bila jumlah tenaga kerja meningkat dan dipekerjakan dengan tepat.

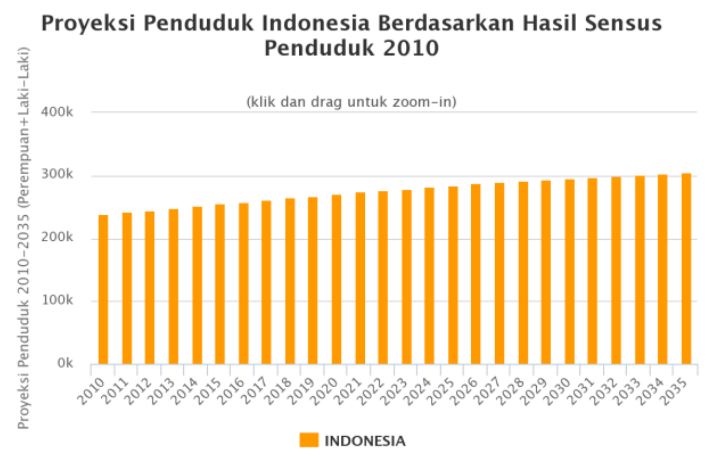

Sumber: Badan Pusat Statistik

\section{Gambar 1.}

\section{Proyeksi Penduduk Indonesia 2010}

Turut terlibatnya penduduk dalam pembangunan ekonomi menjadi hal yang penting karena hal ini mendukung peningkatan pendapatan nasional. Pemerintah dapat membuat kebijakan mengenai perluasan kesempatan kerja yang merupakan sebuah indikator berhasilnya sebuah pembangunan dan tolak ukur keberhasilan negara dalam mencapai kesejahteraan.
Pernikahan yang sejahtera pasti memiliki kesamaan visi dan misi dalam sebuah keluarga.Keluarga merupakan salah satu sistem.Sistem merupakan perangkat komponen yang masing-masing komponen tersebut bergabung menjadi satu dan saling terkait sehingga membentuk satu kesatuan yang utuh. Keluarga merupakan objek dari suatu sistem tersebut dan masing-masing individu mempunyai pengaruh dengan yang lain dan saling berinteraksi.

\section{LANDASAN TEORI}

\section{Pengertian Menikah dalam Islam}

Nikah secara bahasa berarti 'adh dhomm' atau 'al jam'i yang artinya mengumpulkan.Secara istilah syar'i, nikah adalah istilah dari akad yang masyhur yang terdiri dari rukun dan syarat.Secara bahasa nikah bisa bermakna akad dan bermakna menyetubuhi (mencampuri) istri.Al Azhari berkata bahwa asal kata nikah dalam bahasa Arab adalah al wath'u atau menyetubuhi.Ada pula yang menyebut nikah untuk akad pernikahan karena akad inilah yang menyebabkan halalnya persetubuhan. (Lihat Kifayatul Akhyar, 2: 33). Dalil disyari'atkannya nikah,

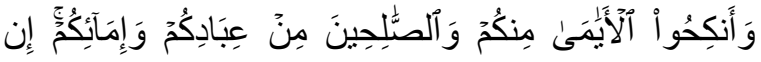

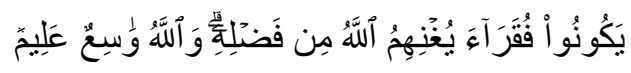
Artinya: "Dan kawinkanlah orang-orang yang sedirian diantara kamu, dan orangorang yang layak (berkawin) dari hambahamba sahayamu yang lelaki dan hamba- 
Fadhil, et al/Jurnal Ekonomi Syariah Teori dan Terapan Vol. 6 No. 8 Agustus 2019: 1674-1689; PENGARUH FAKTOR SOSIAL EKONOMI TERHADAP PERKAWINAN MUSLIM DI INDONESIA

hamba sahayamu yang perempuan. Jika mereka miskin Allah akan memampukan mereka dengan kurnia-Nya. Dan Allah Maha luas (pemberian-Nya) lagi Maha Mengetahui."

Disebutkan dalam hadits bahwa Allah akan senantiasa menolong orang yang ingin menjaga kesucian dirinya lewat menikah. Dari Abu Hurairah radhiyallahu 'anhu bahwasanya Rasulullah shallallahu 'alayhi wa sallam bersabda tentang tiga golongan yang pasti mendapat pertolongan Allah. Di antaranya,

$$
\text { وَالنَّاكِحُ الَّذَي يُرِيدُ الْعَفَافَ }
$$

Wannakihu dzdzii yuril 'afaafa

"... seorang yang menikah karena ingin menjaga kesuciannya." (HR.An Nasai no. 3218, At Tirmidzi no. 1655. Syaikh Al Albani mengatakan bahwa hadits ini hasan).

Ahmad bin Syu'aib Al Khurasani An Nasai membawakan hadits tersebut dalam Bab "Pertolongan Allah bagi orang yang nikah yang ingin menjaga kesucian dirinya".

Rasulullah shallallahu "alayhi wa sallam bersabda,

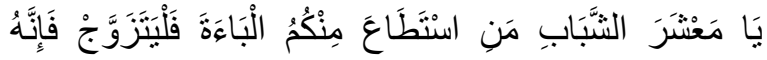

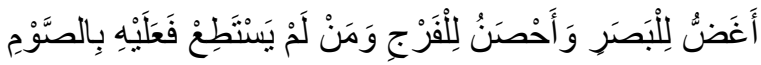
فَإِنَّهُ لَلهُهُ وِجَاءُ

Yaa ma'syarasy syabaabi manistathaa 'a minkumul baa-a ta falyatazaw waj, fainnahu a ghadhdhu lilbashari wa ahshanu lil farji, wa man lam yastathi' fa'alayhi bish shawmi fainnahu lahu wi jaa-un
Artinya: "Wahai para pemuda, barangsiapa yang memiliki baa-ah, maka menikahlah. Karena itu lebih akan menundukkan pandangan dan lebih menjaga kemaluan. Barangsiapa yang belum mampu, maka berpuasalah karena puasa itu bagai obat pengekang baginya." (HR. Bukhari no. 5065 dan Muslim no. 1400).

Melihat dari pengertian di atas, penulis menyimpulkan bahwa pengertian menikah adalah menyatunya dua insan laki-laki dan perempuan dalam suatu ikatan agama yang bertujuan untuk saling melengkapi diri masing-masing dan mempunyai keturunan sesuai dengan syari'at, serta sebagai sarana beribadah kepada Allaah Subhanahu Wa Ta'ala. Dalam Al-Qur'an disebutkan bahwa:

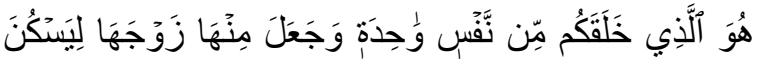

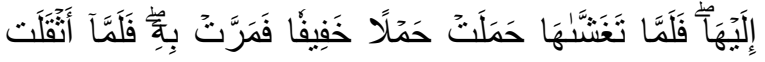

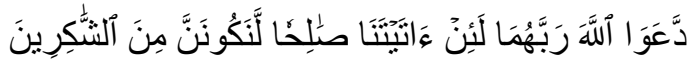
huwa alladhì khalaqakum min nafsin wāhidatin waja 'ala min'hā zawjahā liyaskuna ilayhā falammā taghashāhā hamalat hamlan khafifan famarrat bihi falammā athqalat da'awā I-laha rabbahumā la-in ātaytanāșāliḥan lanakūnanna mina l-shākirīna

Artinya: "Dialah Yang menciptakan kamu dari diri yang satu dan dari padanya Dia menciptakan isterinya, agar dia merasa senang kepadanya. Maka setelah dicampurinya, isterinya itu mengandung kandungan yang ringan, dan teruslah dia 
Fadhil, et al/Jurnal Ekonomi Syariah Teori dan Terapan Vol. 6 No. 8 Agustus 2019: 1674-1689; PENGARUH FAKTOR SOSIAL EKONOMI TERHADAP PERKAWINAN MUSLIM DI INDONESIA

merasa ringan (beberapa waktu). Kemudian tatkala dia merasa berat, keduanya (suami-isteri) bermohon kepada Allah, Tuhannya seraya berkata: "Sesungguhnya jika Engkau memberi kami anak yang saleh, tentulah kami termasuk orang-orang yang bersyukur." [Q.S. Al-A'raf : 189]

Pernikahan adalah Sunnatullah yang umum berlaku pada semua makhluk. Menurut Dr. Khalid Basalamah, pernikahan dalam Islam adalah penyatuan antara dua lawan jenis anak Adam dalam satu ikatan ritual agama yang mengalalkan hubungan biologis di antara keduanya, serta menyatukan antara kedua pasangan keluarga suku dan negara. Maka definisi ini dibagi menjadi tiga:

1. Haram hukumnya dalam Islam untuk menikah sesama jenis. Murni laki-laki dan murni perempuan.

2. Anak adam berarti manusia, sehingga haram untuk menikah dengan selain manusia seperti jin, binatang, dan lainlain.

3. Berhubungan biologis adalah hal yang normal dan merupakan fithrah manusia, maka Allaah Subhanahu Wa Ta'ala mengajarkan manusia untuk melampiaskan fitrahnya dengan cara yang benar, yaitu akad.

4. Menyatukan antara dua keluarga, berarti juga menerima keluarga pasangan masing-masing. Baik kedua orang tua, maupun kerabat-kerabat lainnya.

\section{Pengertian Menikah dalam Ekonomi}

Pernikahan menurut ekonomi didefinisikan sebagai penerapan analisis ekonomi untuk studi pernikahan, telah menghasilkan minat yang sangat terbatas.

Pernikahan dalam Ekonomi mempunyai sebuah pendekatan.Pendekatan tersebut adalah Neo-Classical Economic Analysis of Marriage.Pendekatan ekonomi neo-klasik menggunakan asumsi rasionalitas. Dalam pengambilan keputusan, pendekatan rasional dapat dikomparasikan dengan pendekatan lain yang biasa ditemukan di kalangan intelektual seperti pendekatan Marxis yang menekankan determinisme material, dan pendekatan Freudian yang menekankan kekuatan naluri atas perilaku manusia.

Berikut pemaparan dua alat utama yang digunakan dalam aplikasi umum ekonomi neo-klasik adalah analisis biayamanfaat dan analisis pasar :

1. Analisis Biaya-Manfaat membagi elemen-elemen yang terkait dengan keputusan tertentu menjadi dua kelompok: manfaat dan biaya. Titik optimal tercapai ketika manfaat marjinal sama dengan biaya marjinal. Sebagai contoh, seseorang akan membelanjakan uang untuk margarin hingga jumlah di mana manfaat yang 
diperoleh dari paket margarin sama dengan harganya. Dalam hal ini harga adalah biaya marjinal. Jika suatu barang tidak dijual di pasar, tetapi diproduksi di rumah, manfaat marjinal harus sama dengan biaya marjinal, yang juga ditentukan di rumah, misalnya, sebagai fungsi dari nilai penggunaan alternatif waktu dan uang.

2. Analisis Pasar. Jika suatu barang atau jasa tidak ditakdirkan hanya untuk satu "konsumen," atau tidak diproduksi semata-mata oleh satu produsen, ada pasar, baik secara fisik dapat diamati atau tidak. Ada pasar untuk barang, jasa, dan beberapa pekerjaan yang berbeda seperti insinyur, pengajar, dan lain-lain.

Analisis biaya manfaat dan analisis pasar dapat diterapkan dalam kehidupan pernikahan.Menurut pendekatan ekonomi analisis biaya manfaat, orang menikah ketika perbandingan biaya dan manfaat dilakukan (sadar atau tidak sadar) pernikahan terlihat menguntungkan.Manfaat dapat berupa sosial, materi maupun spiritual.meluangkan waktunya untuk belajar agama.

Alat yang kedua yaitu analisis pasar.Becker dan sosiolog sebelumnya menggunakan istilah "pasar pernikahan". Menurut teori ekonomi perkawinan dalam buku "On The Economics of Marriage A Theory Of Marriage, Labor, and Divorce", pasar perkawinan terdiri dari pasokan tenaga kerja suami-istri yang dipasok oleh suami istri itu sendiri. Masing-masing individu memiliki kewajiban untuk berpartisipasi dalam pasar ini dan melakukan tindakannya sesuai dengan analisis biaya manfaat.Masingmasing individu mencoba untuk memenuhi kebutuhan, dan meningkatkan utilitas mereka sendiri, yang dapat berupa sosial dan spiritual.

\section{METODE PENELITIAN}

\section{Pendekatan Penelitian}

Penelitian ini menggunakan metode penelitian kuantitatif.Metode penelitian kuantitatif merupakan penelitian yang terstruktur dan mengkuantfikasikan data untuk dapat digeneralisasikan. Sebagaimana ditulis oleh Malhotra (1996) : "..... Quantitative research is a research methodology which seeks to quantify the data, and typically, applies some form of statistical analysis..." (Anshori, 2009).

\section{Identifikasi Variabel}

Variabel $X$ leksogen atau independen) yang digunakan dalam pengujian penelitian ini adalah variabel gender, agama, masa haid pertama kali, status pernikahan, pendidikan, pekerjaan, dan usia. Sedangkan variabel $Y$ (endogen atau dependen) adalah keputusan seorang muslim untuk menikah.

\section{Definisi Operasional}


Fadhil, et al/Jurnal Ekonomi Syariah Teori dan Terapan Vol. 6 No. 8 Agustus 2019: 1674-1689; PENGARUH FAKTOR SOSIAL EKONOMI TERHADAP PERKAWINAN MUSLIM DI INDONESIA

Jenis Kelamin

Variabel jenis kelamin merupakan salah satu variabel yang mempengaruhi keputusan menikah seseorang.Jenis kelamin adalah perbedaan biologis antara pria dan wanita, yang bersifat universal dan ditentukan saat lahir (UNESCO, 2003).Dalam data IFLS, variabel jenis kelamin ada pada BukU K bagian AR dengan variabel 'ar07'.

\section{Agama}

Agama merupakan sistem kepercayaan dan praktik yang dipersatukan relatif terhadap hal-hal suci, yaitu, hal-hal yang dipisahkan dan dilarang (Durkheim, 1912).Variabel agama yang ada di dalam IFLS adalah 'ar15' yang ada dalam BUKU K bagian AR. Variabel agama tersebut kemudian dibuat menjadi variabel dummy.

\section{Usia}

Menurut Kamus Besar Bahasa Indonesia (KBBI), usia adalah lama waktu hidup atau ada, sejak dilahirkan atau diadakan. Dalam pernikahan, usia merupakan salah satu variabel yang digunakan seseorang untuk membuat keputusan untuk menikah, baik untuk dirinya sendiri, maupun untuk calon pasangan.

Dari perspektif sosiologis, ada kemungkinan bahwa usia menikah orang dewasa yang berstatus rendah lebih relevan daripada wanita berstatus tinggi (Bumpass, 1969). Variabel usia diambil dari Buku K, bagian AR 1 dengan nama variabel 'ar09'.

\section{Pendidikan}

Menurut UU SISDIKNAS No. 20 Tahun 2003, pengertian pendidikan adalah usaha sadar dan terencana untuk mewujudkan suasana belajar dan proses pembelajaran agar peserta didik secara aktif mengembangkan potensi dirinya untuk memiliki kekuatan spiritual keagamaan, pengendalian diri, kepribadian, kecerdasan, akhlak mulia, serta keterampilan yang diperlukan dirinya dan masyarakat.

Proes pengolahan data untuk variabel pendidikan adalah melalui Buku 3A bagian $D L$, yaitu variabel 'dll la' yang merupakan tahun pertama kali masuk ke tingkat sekolah, dan variabel 'dl4type' yang merupakan jenjang sekolah.

\section{Pekerjaan}

Menurut Kamus Besar Bahasa Indonesia $(\mathrm{KBBI})$, pekerjaan diambil dari kata 'kerja' yang merupakan sesuatu yang dilakukan untuk mencari nafkah atau dapat disebut sebagai mata pencaharian. Sedangkan pekerjaan sendiri merupakan penelaahan secara mendalam dan sistematis, yang dapat memberikan keterangan tentang tugas, tanggung jawab, dan sifat pekerjaan, untuk dapat melaksanakan pekerjaan tersebut dengan baik.

Variabel pekerjaan diambil dari BukU 3A, bagian TK 4, dan variabel yang diambil adalah 'tk47yr' yang merupakan 
pertama kalinya seseorang mempuyai pekerjaan penuh atau pekerjaan sebagai kegiata utama.

\section{Masa Haid Pertama Kali}

Menstruasi adalah ketika darah dan jaringan dari rahim keluar dari vagina seorang perempuan, dan ini biasanya terjadi setiap bulan (planned parenthood.org). Dalam data IFLS, variabel menstruasi atau haid ada dalam Buku 3A, bagian KW dengan variabel 'kw23b' yang merupakan umur pertama kali mengalami menstruasi.

\section{Jenis dan Sumber Data}

Penelitian ini menggunakan data sekunder yang diambil dari IFLS (Indonesian Family Life Survey). IFLS merupakan survei longitudinal. Sekitar $83 \%$ sampel dari populasi di Indonesia yang mencakup kurang lebih 30.000 orang diambil di 13 dari 27 propinsi di Indonesia.

\section{Teknik Analisis}

Penelitian ini menggunakan data cross section, yaitu data yang dikumpulkan menggunakan kurun waktu tertentu dari sampel (Widarjono, 2007), dan menggunakan teknik analisis Regresi OLS (Ordinary Least Square).Metode OLS merupakan metode untuk mengestimasi suatu garis regresi di mana jumlah kuadrat diminimalisir kesalahannya dari setiap observasi terhadap garis tersebut (Kuncoro, 2003).

\section{Model dengan Variabel Dependen Bentuk Biner atau Dummy}

Banyak pilihan-pilihan yang dibuat oleh individu maupun perusahaan merupakan "either-or" yang artinya "baik—atau". Sebagai contoh, seperti :

1. Seorang murid yang sudah lulus SMA memutuskan baik melanjutkan kuliah atau tidak.

2. Seorang pekerja memutuskan baik menggunakan kendaraan pribadi atau menggunakan transportasi umum.

Hill et Al. (2011) tertarik untuk menjelaskan mengapa pilihan-pilihan tertentu dibuat, dan faktor-faktor apa yang masuk ke dalam proses pengambilan keputusan. Tujuan lainnya adalah untuk tahu seberapa besar masing-masing faktor mempengaruhi hasil. Pertanyaanpertanyaan semacam itu membawa kita pada masalah membangun model statistik pilihan biner, baik - atau,.Pilihan tersebut dapat diwakili oleh variabel biner (indikator) yang mengambil nilai 1 jika satu hasil dipilih dan nilai 0 untuk sebaliknya.Variabel biner yang menggambarkan pilihan adalah variabel dependen daripada variabel independen. Fakta ini memengaruhi pilihan kita akan model statistik.

Di sini akan digambarkan model pilihan biner menggunakan masalah penting dari transportasi ekonomi.

Bagaimana kita bisa menjelaskan pilihan individu antara mengemudi 
Fadhil, et al/Jurnal Ekonomi Syariah Teori dan Terapan Vol. 6 No. 8 Agustus 2019: 1674-1689; PENGARUH FAKTOR SOSIAL EKONOMI TERHADAP PERKAWINAN MUSLIM DI INDONESIA

(transportasi pribadi) dan naik bus (transportasi umum) ketika pulang kerja, dengan asumsi, untuk kesederhanaan, bahwa ini adalah dua alternatif saja? Pilihan individu diwakili dengan variabel indikator

$$
y=\left\{\begin{array}{l|l|}
1 & \begin{array}{l}
\text { Individu yang } \\
\text { mengemudi sendiri }
\end{array} \\
\cline { 2 - 2 } 0 & \begin{array}{l}
\text { Individu yang } \\
\text { mengendarai } \\
\text { transportasi umum }
\end{array} \\
\hline
\end{array}\right.
$$

Jika kami mengumpulkan sampel acak pekerja yang naik bus saat pergi kerja, maka hasilnya y tidak akan diketahui oleh kami sampai sampel diambil. Jadi, y adalah variabel acak. Jika probabilitas bahwa seorang individu mengemudi untuk bekerja adalah $P, P[y=1]=p$ Ini mengikuti probabilitas bahwa seseorang menggunakan transportasi umum adalah $P$ $[y=0]=1 \oplus$. Fungsi probabilitas untuk variabel acak biner tersebut adalah

$$
f(y)=p^{y}(1-p)^{1-y}, \quad y=0,1
$$

di mana $p$ adalah probabilitas bahwa y mengambil nilai satu. Variabel acak diskrit ini memiliki nilai yang diharapkan $E(y)=p$ dan varians $\operatorname{var}(y)=P(1-$ p). Faktor-faktor apa yang mungkin memengaruhi probabilitas seseorang memilih satu transportasi daripada yang lain? Satu faktor tentu akan berapa lama untuk bisa bekerja dengan satu cara atau yang lain. Tentukan variabel penjelas $x=$ (waktu perjalanan dengan bus - waktu perjalanan dengan mobil)

Ada faktor-faktor lain yang mempengaruhi keputusan, tetapi marilah kita fokus pada variabel penjelas tunggal ini. Dari yang sebelumnya diperkirakan saat $x$ bertambah, dan waktu perjalanan dengan bus meningkat relatif terhadap waktu perjalanan dengan mobil, seseorang akan lebih cenderung mengemudi. Artinya, diharapkan hubungan positif antara $x$ dan p, probabilitas bahwa seorang individu akan mendorong untuk bekerja.

Pengertian Regresi LPM (Linear Probability Model)

Salah satu cara untuk memodelkan pilihan biner adalah dengan model probabilitas linier. Ada beberapa masalah dengan menggunakan model probabilitas linier.Ini menyiratkan efek marginal dari perubahan dalam variabel penjelas kontinu adalah konstan, yang tidak dapat menjadi kasus untuk model probabilitas. Model ini juga dapat menghasilkan probabilitas yang diprediksi di luar interval $[0,1]$. Istilah kesalahan model probabilitas linier adalah heteroskedastik, sehingga penduga yang lebih baik adalah generalisasi kuadrat terkecil

\section{Pengertian Regresi Logit Model}

Estimasi model probit secara numerik rumit karena didasarkan pada distribusi normal.Alternatif yang sering digunakan untuk model probit untuk situasi pilihan biner 
adalah model logit.Model-model ini berbeda hanya dalam kurva berbentuk $S$ tertentu yang digunakan untuk membatasi probabilitas ke interval $[0,1]$.

\section{Pengertian Regresi Probit (Normit Model)}

Untuk menjaga probabilitas pilihan $\mathrm{p}$ dalam interval $[0,1]$, hubungan berbentuk $S$ nonlinear antara $x$ dan $P$ dapat digunakan.Pada Gambar 3.1kurva seperti itu diilustrasikan. Ketika $x$ meningkat, kurva probabilitas naik dengan cepat pada awalnya, dan kemudian mulai meningkat pada tingkat yang menurun.

Kemiringan kurva ini memberikan perubahan probabilitas mengingat perubahan satuan dalam $x$. Kemiringan tidak konstan seperti pada model probabilitas

linier.

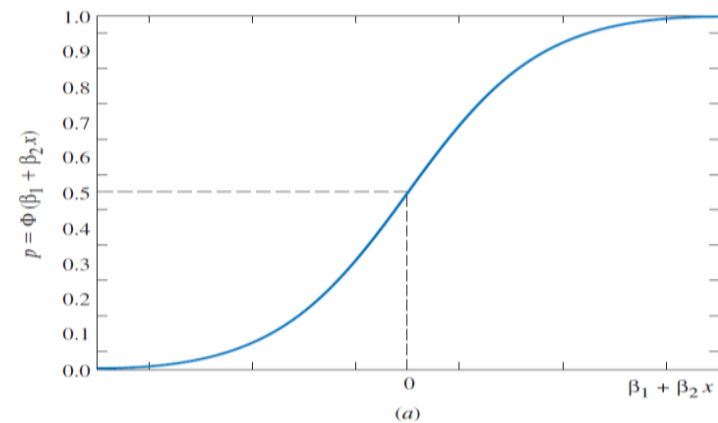

Gambar 2.

Standard normal fungsi distribusi kumulatif

Hubungan fungsional yang digunakan untuk mewakili kurva tersebut adalah fungsi probit.Fungsi probit terkait dengan distribusi probabilitas normal standar.

\section{HASIL DAN PEMBAHASAN}

Pembahasan Hasil Regresi
Penelitian ini bertujuan untuk mengetahui faktor apa saja yang mempengaruhi keputusan seorang muslim untuk menikah. Variabel yang peneliti gunakan untuk menguji pengaruh keputusan menikah seorang muslim adalah variabel usia, variabel pendidikan, dan variabel pekerjaan. Teknik analisis yang digunakan adalah model regresi OLS (Ordinary Least Squares).Penelitian ini menggunakan tiga jenis regresi, yaitu LPM, Probit, dan Logit.Pengolahan data menggunakan aplikasi stata MP (for windows). Tingkat signifikansi Alfa yang digunakan adalah $0,05(a=5 \%)$ atau tingkat kepercayaan sebesar 0,95 (95\%).

\section{PEMBAHASAN}

Model Regresi I untuk Seluruh Sampel Tabel 1.

\section{Model Regresi I Untuk Semua Sampel}

\begin{tabular}{|c|c|c|c|}
\hline Variabel & LPM & Logit & Probit \\
\hline \multirow{2}{*}{$\begin{array}{l}\text { Pria (Pria=1, } \\
\text { Perempuan=0) }\end{array}$} & $-0.431772 * * *$ & $-0.6001848 * * *$ & $-0.5538248 * * *$ \\
\hline & {$[0.0120242]$} & {$[0.01727]$} & {$[0.01596]$} \\
\hline \multirow{2}{*}{$\begin{array}{l}\text { (Muslim=1, Non- } \\
\text { muslim=0) }\end{array}$} & $0.021774^{*}$ & $0.0398357^{*}$ & $0.045745^{*}$ \\
\hline & {$[0.0192541]$} & {$[0.03534]$} & {$[0.03214]$} \\
\hline \multirow{2}{*}{ Usia } & $0.0276952 * * *$ & $0.0508813^{* * *}$ & $0.412127 * * *$ \\
\hline & {$[0.0007056]$} & {$[0.00173]$} & {$[0.00132]$} \\
\hline \multirow{2}{*}{ Pendidikan } & $-0.0253631^{* * *}$ & $-0.0644159 * * *$ & $-0.0425329 * * *$ \\
\hline & {$[0.0059058]$} & {$[0.01088]$} & {$[0.00979]$} \\
\hline \multirow{2}{*}{ Pekerjaan } & $-7.59 \mathrm{E}-06^{*}$ & $-0.0000193^{*}$ & $-0.0000136^{*}$ \\
\hline & {$[0.00000883]$} & {$[0.00001]$} & {$[0.00001]$} \\
\hline \multicolumn{4}{|l|}{ Keterangan: } \\
\hline \multicolumn{4}{|l|}{ signifikan $1 \%=* * *$} \\
\hline \multicolumn{4}{|l|}{ signifikan $5 \%=* *$} \\
\hline \multicolumn{4}{|l|}{ signifikan $10 \%=*$} \\
\hline \multicolumn{4}{|c|}{ Angka dalam kurung adalah standard error } \\
\hline
\end{tabular}

Berdasarkan hasil olah data, didapatkan hasil regresi LPM, logit dan probit yang menunjukkan bahwa variabel pria, usia, dan pendidikan berpengaruh signifikan terhadap keputusan seseorang 
untuk menikah yang terbukti dari p-value masing-masing variabel sebesar 0,000 di mana nilai probabilitas ini lebih kecil dari nilai signifikansi $1 \%$.

Untuk variabel muslim mempunyai $p$ value sebesar 0,258 dalam regresi LPM, Ialu 0,260 dalam regresi logit dan 0,155 dalam regresi probit. Hasil variabel muslim ini menunjukkan bahwa tidak adanya pengaruh terhadap keputusan menikah seorang indiviu secara umum di Indonesia.

Kemudian pada variabel usia dan pendidikan, menunjukkan di ketiga regresi bahwa usia dan pendidikan berpengaruh secara signifikan terhadap keputusan menikah individu secara umum di Indonesia karena sama-sama mempunyai p-value sebesar 0,000 yang lebih kecil dibanding signifikansi $1 \%$.

Variabel pekerjaan dengan p-value sebesar 0,390 dalam regresi LPM, 0,19 dalam regresi logit dan 0,31 dalam regresi probit di mana angka ini lebih besar dari nilai signifikansi $10 \%$ sehingga tidak memberikan pengaruh signifikan terhadap keputusan seorang individu untuk menikah secara umum. Berikut merupakan persamaan regresi untuk Model I:

1. Persamaan Hasil Regresi LPM :

Probabilitas (nikah) $=0,045-0,432$ jenis kelamin $+0,022$ agama $+0,028$ usia $-0,025$ pendidikan $-0,00008$ kerja

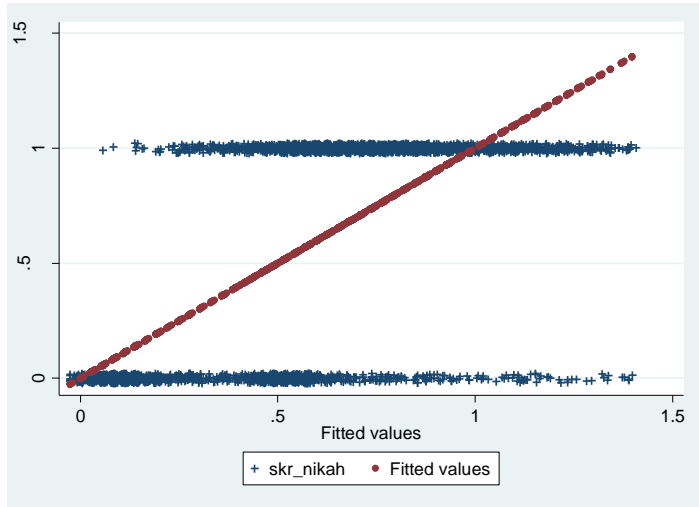

Gambar 3.

Hasil plotting estimasi LPM

Hasil plotting estimasi LPM pada model I menunjukkan permasalahan LPM.Grafik di atas menunjukkan adanya hasil di atas nilai 1 yang melebihi batas dan berada di luar interval.

2. Persamaan Hasil Regresi Logit

Probabilitas (nikah) $=-3,6251-0,6002$ jenis kelamin $+0,040$ agama $+0,051$ usia $-0,0644$ pendidikan - 0,0002 kerja

3. Persamaan Hasil Regresi Probit

Probabilitas $($ nikah) $=-1,8256-0,554$ jenis kelamin $+0,046$ agama $+0,0412$ usia $-0,043$ pendidikan - 0,0000136 kerja

\section{Model Regresi II untuk Sampel Muslim}

Tabel 2.

\section{Model Regresi II untuk Seluruh Sampel \\ Muslim}




\begin{tabular}{|c|c|c|c|}
\hline Variabel & LPM & Logit & Probit \\
\hline \multirow{2}{*}{$\begin{array}{l}\text { Pria }(\text { Pria }=1, \\
\text { Perempuan }=0)\end{array}$} & $-0.4315873^{* * *}$ & $-0.6044842^{* * * *}$ & $-0.557402^{* * *}$ \\
\hline & {$[0.0126354]$} & [0.01826] & {$[0.01687]$} \\
\hline \multirow{2}{*}{ Usia } & $0.0279565^{* * *}$ & $0.0518321 * * *$ & $0.0421125^{* * *}$ \\
\hline & [0.0007414] & [0.00184] & {$[0.0014]$} \\
\hline \multirow{2}{*}{ Pendidikan } & $-0.0269444^{* * * *}$ & $-0.0686319^{* * *}$ & $-0.0468536^{* * * *}$ \\
\hline & {$[0.0062001]$} & [0.01153] & {$[0.01037]$} \\
\hline \multirow{2}{*}{ Pekerjaan } & -0.0000132 & $-0.0000292 *$ & $-0.0000219^{*}$ \\
\hline & [9.33E-06] & {$[0.00002]$} & {$[0.00001]$} \\
\hline \multicolumn{4}{|l|}{ Keterangan : } \\
\hline \multicolumn{4}{|c|}{ signifikan $1 \%=* * *$} \\
\hline \multicolumn{4}{|c|}{ signifikan $5 \%=* *$} \\
\hline \multicolumn{4}{|l|}{ signifikan $10 \%=*$} \\
\hline \multicolumn{4}{|c|}{ Angka dalam kurung adalah standard error } \\
\hline
\end{tabular}

Dalam tabel di atas, didapatkan hasil regresi LPM, logit dan probit yang menunjukkan bahwa p-value dari variabel dummy pria, usia, dan pendidikan sebesar 0,000, sehingga berpengaruh signifikan terhadap keputusan seorang muslim untuk menikah dan terbukti dimana nilai probabilitas lebih kecil dari nilai signifikansi $1 \%$.

Variabel pekerjaan dengan p-value sebesar 0,157 dalam regresi LPM, 0,058 dalam regresi logit dan 0,118 dalam regresi probit di mana angka ini lebih besar dari nilai signifikansi $5 \%$ dan $10 \%$ sehingga tidak memberikan pengaruh signifikan terhadap keputusan seorang muslim untuk menikah.Berikut merupakan persamaan regresi untuk Model II:

\section{Persamaan Hasil Regresi LPM}

Probabilitas $($ nikah) $=0,064-0,432$ jenis kelamin $+0,028$ usia $-0,027$ pendidikan 0,0000132 kerja

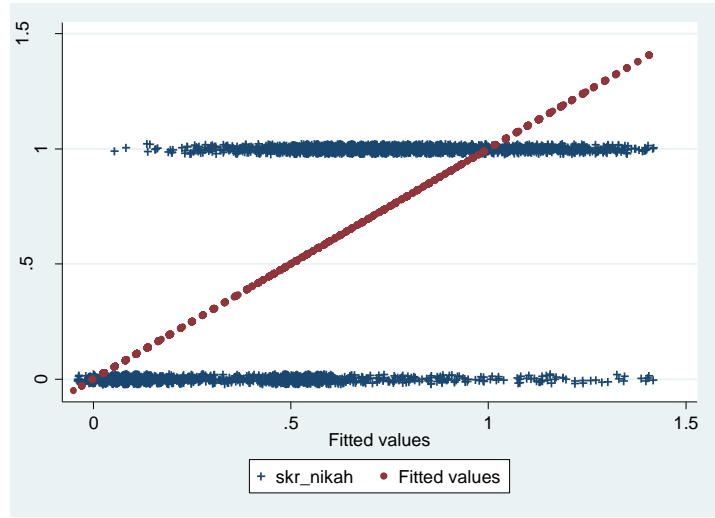

Gambar 4.

\section{Hasil plotting estimasi LPM}

Hasil plotting estimasi LPM pada model II menunjukkan permasalahan LPM. Dalam grafik di atas, variabel 'skr_nikah' merupakan variabel status perkawinan yang merupakan variabel dummy di mana nilai 1 untuk yang sudah menikah dan nilai 0 untuk yang belum menikah. Grafik di atas menunjukkan adanya hasil di atas nilai 1 dan di bawah nilai 0 yang melebihi batas dan berada di luar interval.

1. Persamaan Hasil Regresi Logit

Probabilitas (nikah) $=-3,5032-0,6045$

jenis kelamin $+0,052$ usia $-0,069$

pendidikan - 0,00003 kerja

2. Persamaan Hasil Regresi Probit

Probabilitas $($ nikah) $=-1,734-0,56$ jenis kelamin $+0,042$ usia $-0,047$ pendidikan 0,0000210 kerja

\section{Model Regresi III untuk Sampel Perempuan} Tabel 3. 
Model Regresi III untuk Sampel Seluruh

Perempuan

\begin{tabular}{|c|r|r|r|}
\hline Variabel & \multicolumn{1}{|c|}{ LPM } & \multicolumn{1}{c|}{ Logit } & \multicolumn{1}{c|}{ Probit } \\
\hline $\begin{array}{c}\text { (Muslim=1, Non- } \\
\text { muslim=0) }\end{array}$ & $-0.285237^{* * *}$ & $-0.0332069^{* * *}$ & $-0.3450813^{* * *}$ \\
\cline { 2 - 4 } & {$[0.1022312]$} & {$[0.06654]$} & {$[0.06344]$} \\
\hline \multirow{2}{*}{ Usia } & $-0.0173348^{* * *}$ & $-0.0185984^{* * *}$ & $-0.0188714^{* * *}$ \\
\cline { 2 - 4 } & {$[0.0044589]$} & {$[0.00569]$} & {$[0.0056]$} \\
\hline \multirow{2}{*}{ Pekerjaan } & $-0.0000556^{* * *}$ & $-0.0000658^{* * *}$ & $-0.0000645^{* * *}$ \\
\cline { 2 - 4 } & {$[0.0000163]$} & {$[0.00002]$} & {$[0.00002]$} \\
\hline Masa Haid Pertama & $-5.79 \mathrm{E}-03$ & -0.0067067 & -0.0055995 \\
\cline { 2 - 4 } Kali & {$[0.0179382]$} & {$[0.02024]$} & {$[0.2004]$} \\
\hline Keterangan : \\
\hline signifikan 1\% $=* * *$ \\
\hline signifikan 5\% $=* *$ \\
\hline signifikan 10\% $=*$ \\
\hline Angka dalam kurung adalah standard error \\
\hline
\end{tabular}

Berdasarkan hasil olah data, didapatkan hasil regresi LPM, logit dan probit. Pada regresi LPM, p-value variabel dummymuslim sebesar 0,006, variabel usia dan pekerjaan sebesar 0,000 dan 0,001 di mana nilai probabilitas lebih kecil dan sama dengan 1\%. Sehingga, variabel dummy muslim, usia dan pekerjan berpengaruh secara signifikan terhadap keputusan seorang perempuan untuk menikah secara umum.

Pada regresi logit, variabel dummymuslim mempunyai $p$-value sebesar 0,000 , variabel usia 0,001 dan variabel pekerjaan 0,007. Menunjukkan bahwa variabel dummy muslum, usia, dan pekerjaan berpengaruh secara signifikan terhadap probabilitas menikah seorang perempuan dibuktikan dengan p-value yang lebih kecil dari $1 \%$.

Dalam regresi probit, variabel usia mempunyai $p$-value sebesar 0,001 , variabel dummy muslim sebesar 0,000 dan variabel pekerjaan sebesar 0,003. Hal ini menunjukkan bahwa variabel usia, dummy muslim dan pekerjaan berpengaruh secara signifikan terhadap keputusan seorang perempuan secara umum di Indonesia untuk menikah. Hasil ini dibuktikan karena pvalue yang lebih kecil dibanding $1 \%$.

Variabel masa haid pertama kali, tidak berpengaruh dalam keputusan menikah seorang perempuan. Pada regresi LPM, $p$-value sebesar 0,75 , pada regresi logit sebesar 0,740, dan p-value regresi probit sebesar 0,780.Berikut merupakan persamaan regresi untuk Model III :

1. Persamaan Hasil Regresi LPM

Probabilitas (nikah) $=2,031-0,285$ agama

- 0,017 usia - 0,000056 kerja - 0,05793 masa haid pertama kali

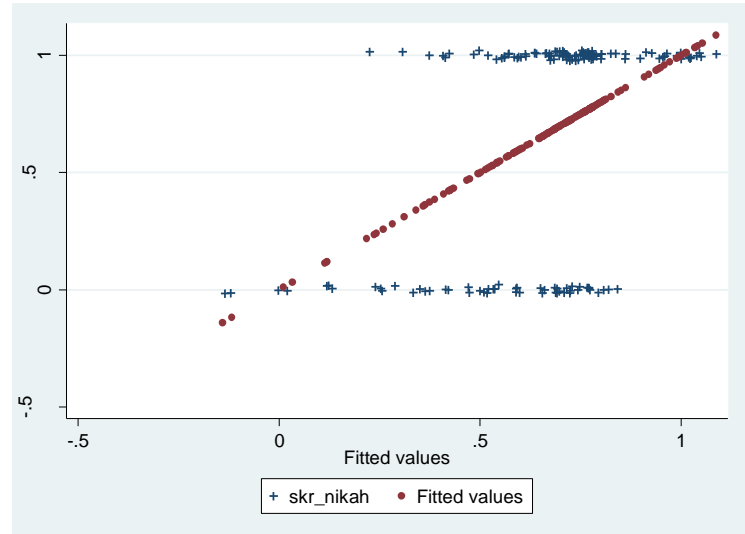

Gambar 5.

Hasil plotting estimasi LPM

Hasil plotting estimasi LPM pada model III menunjukkan permasalahan LPM. Dalam grafik di atas, variabel 'skr_nikah' merupakan variabel status perkawinan yang merupakan variabel dummy di mana nilai 1 untuk yang sudah menikah dan nilai 0 untuk yang belum menikah. Grafik di atas menunjukkan adanya hasil di atas nilai 1 
yang melebihi batas dan di bawah nilai 0 sehingga berada di luar interval.

2. Persamaan Hasil Regresi Logit

Probabilitas (nikah) $=8,850-0,0332$ agama - 0,0186 usia - 0,000066 kerja 0,0067 masa haid pertama kali

3. Persamaan Hasil Regresi Probit Probabilitas (nikah) $=5,304-0,345$ agama - 0,019 usia - 0,000065 kerja 0,0056 masa haid pertama kali

\section{Model Regresi IV untuk Sampel Perempuan} Muslim

Tabel 4.

Model Regresi IV (Seluruh Sampel Perempuan Muslim)

\begin{tabular}{|c|r|r|r|}
\hline Variabel & \multicolumn{1}{|c|}{ LPM } & \multicolumn{1}{|c|}{ Logit } & \multicolumn{1}{c|}{ Probit } \\
\hline \multirow{2}{*}{ Usia } & $-0.0177251^{* * *}$ & $-0.0202561^{* * *}$ & $-0.0201286^{* * *}$ \\
\cline { 2 - 4 } & {$[0.0048125]$} & {$[0.00618]$} & {$[0.00599]$} \\
\hline \multirow{2}{*}{ Pekerjaan } & $-0.00005^{* * *}$ & $-0.0000594^{* * *}$ & $-0.0000587^{* * *}$ \\
\cline { 2 - 4 } & {$[0.000018]$} & {$[0.00003]$} & {$[0.00002]$} \\
\hline $\begin{array}{c}\text { Masa Haid Pertama } \\
\text { Kali }\end{array}$ & $-6.18 \mathrm{E}-03$ & -0.0082421 & -0.006903 \\
\cline { 2 - 4 } & {$[0.0196396]$} & {$[0.0225]$} & {$[0.02186]$} \\
\hline Keterangan : \\
\hline signifikan 1\% =*** \\
\hline signifikan 5\% =** \\
\hline signifikan 10\% $=*$ \\
\hline Angka dalam kurung adalah standard error \\
\hline
\end{tabular}

Pada regresi LPM, variabel usia mempunyai $p$-value sebesar 0,000 . Pada regresi logit dan probit mempunyai $p$-value sebesar 0,001 yang berarti berpengaruh signifikan terhadap keputusan menikah seorang perempuan muslim karena mempunyai nilai probabilitas yang lebih kecil dibanding signifikansi $1 \%$.

Variabel pekerjaan pada regresi LPM mempunyai $p$-value sebesar 0,006 yaitu lebih kecil dari signifikansi 1\%.Pada regresi logit mempunyai $p$-value sebesar 0,018 dan pada regresi probit $p$-value sebesar 0,012 yaitu lebih kecil dari signifikansi 5\%.Karena regresi LPM mempunyai masalah seperti yang sudah dibahas sebelumnya.Maka regresi probit dan regresi logitlah yang digunakan sebagai hasil akhir.Pada regresi logit dan regresi probit, variabel pekerjaan berpengaruh secara signifikan karena $p$ value yang lebih kecil dibandingkan signifikansi $5 \%$.

Variabel masa haid pertama kali tidak berpengaruh signifikan terhadap keputusan seorang perempuan muslim untuk menikah karena $p$-value dalam regresi LPM sebesar 0,754 , dalam logit sebesar 0,714 dan dalam probit sebesar 0,752.Berikut merupakan persamaan hasil regresi untuk Model IV:

1. Persamaan Hasil Regresi LPM

Probabilitas (nikah) $=1,77-0,018$ usia 0,00005 kerja - 0,00618 masa haid pertama kali

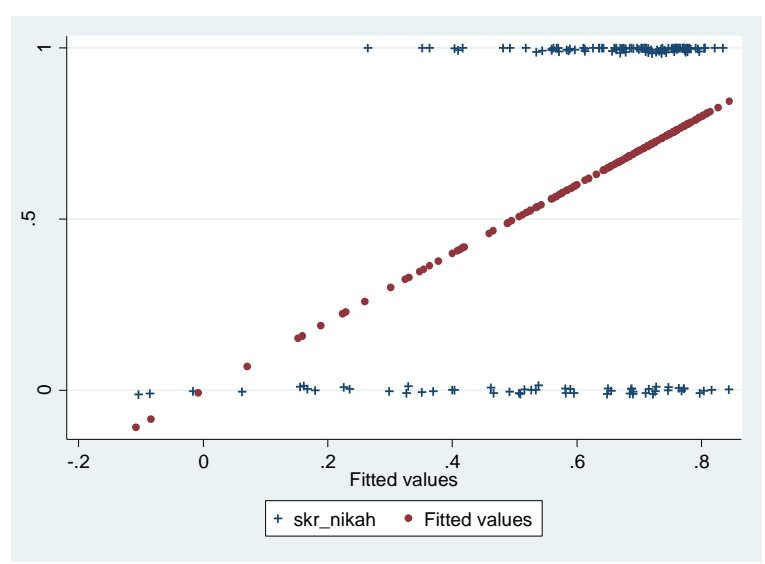

Gambar 6.

Hasil plotting estimasi LPM

Hasil plotting estimasi LPM pada model IV menunjukkan permasalahan LPM. 
Fadhil, et al/Jurnal Ekonomi Syariah Teori dan Terapan Vol. 6 No. 8 Agustus 2019: 1674-1689; PENGARUH FAKTOR SOSIAL EKONOMI TERHADAP PERKAWINAN MUSLIM DI INDONESIA

Dalam grafik di atas, variabel 'skr_nikah' merupakan variabel status perkawinan yang merupakan variabel dummy di mana nilai 1 untuk yang sudah menikah dan nilai 0 untuk yang belum menikah. Grafik di atas menunjukkan adanya hasil di bawah nilai 0 sehingga berada di luar interval.

2. Persamaan Hasil Regresi Logit

Probabilitas (nikah) $=6,16-0,0203$ usia 0,00006 kerja - 0,0082 masa haid pertama kali

3. Persamaan Hasil Regresi Probit

Probabilitas (nikah) $=3,73-0,02013$ usia - 0,00006 kerja - 0,007 masa haid pertama kali

\section{SIMPULAN DAN SARAN}

\section{Kesimpulan}

Dapat ditarik kesimpulan sebagai berikut:

1. Determinan keputusan menikah pada individu secara umum di Indonesia adalah gender, agama, usia, pendidikan dan pekerjaan.

2. Determinan keputusan menikah pada individu muslim di Indonesia adalah gender, usia, pendidikan, dan pekerjaan.

3. Determinan keputusan menikah pada perempuan secara umum di Indonesia adalah agama, usia, dan pekerjaan.

4. Determinan keputusan menikah pada perempuan muslim di Indonesia adalah usia dan pekerjaan.

\section{Saran}

Berdasarkan hasil penelitian di atas, penulis ingin memberikan saran terkait dengan penelitian mengenai determinan sosial ekonomi perkawinan muslim di Indonesia :

1. Pada penelitian selanjutnya, disarankan untuk mempunyai kriteria yang lebih spesifik dalam menentukan objek, sehingga data yang diapatkan akan lebih detail. Selain itu, diharapkan untuk dapat lebih spesifik dalam menggunakan periode untuk penelitian.

2. Penulis menemukan bahwa pria yang sudah bekerja masih saja menunda keputusannya untuk menikah. Sesuai dengan hadits dari Abu Hurairah radhiyallahu 'anhu, ia berkata bahwa Rasulullaah shallallaahu 'alayhi wa sallam bersabda,

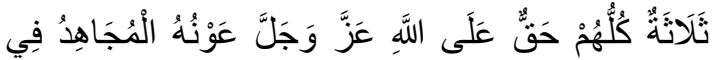

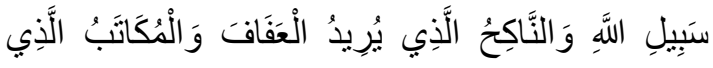
الألَدَدَاءَ

"Ada tiga orang yang akan mendapatkan pertolongan Allah: (1) orang yang berjihad di jalan Allah, (2) orang yang menikah demi menjaga kesucian dirinya, (3) budak mukatab yang ingin membebaskan dirinya." (HR. An-Nasa'i, no. 3218; Tirmidzi, no. 1655; Ibnu Majah, no. 2518.Al-Hafizh Abu Thahir mengatakan bahwa sanad hadits ini hasan). 
Fadhil, et al/Jurnal Ekonomi Syariah Teori dan Terapan Vol. 6 No. 8 Agustus 2019: 1674-1689; PENGARUH FAKTOR SOSIAL EKONOMI TERHADAP PERKAWINAN MUSLIM DI INDONESIA

\section{DAFTAR PUSTAKA}

Bumpass, L. 1969. Age at Marriage as a Variable in Socio-Economic Differentials in Fertility.Demography, $6(1), 45$.

Hosmer, D. dan W S.Lemeshow. 2000. Applied Logistic Regression2nd Edition. New York: John Willey and Sons

Perry, S. L. 2014. A Match Made in Heaven? Religion-Based Marriage Decisions, MaritalQuality, and the Moderating Effects ofSpouse's Religious Commitment. Social Indicators Research

Sugiyono.2013.Metodelogi Penelitian Kuantitatif, Kualitatif Dan R\&D. (Bandung: ALFABETA)

Surjoamihardjo. 1962. Karya K.H. Dewantara, Bagian Pertama: Pendidikan . Jogjakarta: Madjelis Luhur Persatuan Taman Siswa.

Wolfinger, Nick.2016.Replicating the Goldilocks Theory of Marriage and Divorce. USA : University of Utah. 